\title{
SOME VISUAL STRATEGIES IN SYMBOLIC ILLUSTRATED ADVERTISING
}

\section{ALGUNAS ESTRATEGIAS VISUALES EN LA PUBLICIDAD ILUSTRADA SIMBÓLICA}

Peter M. Daly

McGill University, Montreal, Canada

\begin{abstract}
Some symbolic illustrated advertising may remind one of emblems. It is certainly visual culture, but it is also an aspect of emblematics in the material culture. I write from a European perspective, drawing largely on European and American publications. The AIDA formula well sums up the purposes of commercial advertising, and is said to consist of attracting Attention, arousing Interest, creating Desire, and motivating Action. In commercial advertising the desired action is the sale of a product or service. This calls for strategies of persuasion, which can be described rhetorically or thematically. I prefer the thematic approach, and have decided that least following strategies will be discovered: recognition and surprise, riddle and puzzle, wit and humour, patriotism, famous persons, myth, ethnicity, Bible and Christian tradition, and nature, environment and ecology. These are not listed hierarchically and a given ad may employ several of these strategies.
\end{abstract}

KEYWORDS: Emblems; Advertising; Advertising Strategies.

RESUMEN: Ciertos ejemplos de la publicidad ilustrada simbólica nos hacen pensar en la emblemática. Sin duda se trata de la cultura visual, pero constituye al mismo tiempo un aspecto de la emblemática en la cultura material. Mi perspectiva es europea, y los ejemplos aducidos se originan principalmente en publicaciones europeas y norteamericanas. La llamada fórmula AIDA resume muy bien los propósitos de la publicidad comercial, y consiste en llamar la Atención, suscitar el Interés, crear el Deseo y motivar la Acción. En la publicidad comercial la acción deseada es la venta de un producto o servicio. Esto requiere estrategias de la persuasión, las cuales pueden ser descritas retórica o temáticamente. Prefiero un acercamiento temático y concluyo que las siguientes estrategias se revelarán: reconocimiento y sorpresa, adivinanza y enigma, ingenio y humorismo, patriotismo, personas famosas, mito, etnicidad, Biblia y la tradición cristiana, así como naturaleza, medio ambiente y ecología. Esta lista no pretende ser jerárquica y un anuncio publicitario puede utilizar varias de estas estrategias.

PALABRAS CLAVES: Emblemas; publicidad; estrategias de la publicidad. 
I have spent my life studying various forms of symbology: from German baroque literature through Shakespeare and emblems to modern advertising and logos. Readers will hopefully forgive me if I treat forms of illustrated advertising, a topic that would doubtless have interested Víctor Infantes. This is visual culture but it is also an aspect of emblematics in the material culture. Spanish colleagues will find many similar things in Spanish culture. Some people may have read novels by Dan Brown or seen the film versions of The Da Vinci Code or Angels and Demons, and they will recall that the hero is a fictional character, the Harvard symbologist Robert Langdon. I am not Langdon, but I do know something about symbolism. Dan Brown fans will know that his recent books, The Lost Symbol and Inferno, will likely become the basis for films. Could the more recent novels have been written with eventual film versions in mind?

When it comes to advertising I write from a European perspective, and my examples come largely from European and American publications of the 1990s.

There is a formula that well sums up the purposes of commercial advertising. That formula, often known simply as AIDA, is said to consist of the following:

\title{
ATTRACTING ATTENTION \\ AROUSING INTEREST \\ CREATING DESIRE \\ MOTIVATING ACTION.
}

To be effective today the printed ad must catch the reader's eye in the few seconds that it takes to turn a page. When the ad has got our attention the famous AIDA formula comes into play. AIDA stands, as was noted, for Attention, Interest, Desire and Action. In the case of commercial advertising, the desired action, of course, is the sale of a product or a service.

I should say at the outset that I am primarily interested in illustrated symbolic advertising. Persuading us to buy goods and services calls for certain strategies of persuasion. Here I tend to take a thematic approach, asking how symbolic advertisements attract attention and arouse interest through various strategies. I have studied many examples, and have decided that at least the following strategies may be discovered:

\author{
RECOGNITION AND SURPRISE \\ RIDDLE AND PUZZLE \\ WIT AND HUMOUR \\ PATRIOTISM \\ FAMOUS PERSONS \\ MYTH \\ ETHNICITY \\ BIBLICAL AND CHRISTIAN TRADITION \\ NATURE, ENVIRONMENT AND THE ECOLOGY.
}

These are not listed in any hierarchical fashion, and I can usually only reproduce one or two of the many examples that I have accumulated, although I may well describe several others. As far as I can see, almost any historical series of newspapers or magazines will provide further examples of the advertisements that I provide. One realizes that digital forms of storage of back numbers of newspapers or magazines may not necessarily contain the advertisements, which absence the cultural historian may regard as a pity.

It seems to me that most symbolic advertisements draw upon one or more of the strategies, listed above. For the sake of clarity I am isolating them into self-contained groups, 
but in fact they often overlap. For example, a given ad by Ralph Lauren for a perfume may employ sex, patriotism and sport to make its point.

As always we should distinguish between intention and reception. I do not always know in detail what the advertiser intended, but in terms of my reception I think that I know which buttons have been pushed.

\section{RECOGNITION AND SURPRISE}

Products may be so well-known as to require no introduction but they still need to be kept before the consumer. Brand recognition is the name of the game. Such recognition can be as straightforward as a company name, or logo. Which car enthusiast does not recognise the leaping jaguar, the VW or Toyota logo, or the Mercedes star? Advertisers now frequently add something to brand recognition, something that could be called «surprise». This strategy then combines recognition and surprise.

Buying an orange liqueur for the home, or ordering in a restaurant, we may be faced with the choice of Grand Marnier, Triple Sec or Cointreau, to name but three. Which do we select and why? Grand Marnier has advertised its liqueur through a series of illustrated and symbolic ads that feature the bottle, or parts of it, and the all-important orange --these represent the elements of recognition. Surprise is provided by the setting. But each of these ads also has a brief caption, somewhat like the motto or the inscriptio of an emblem, and this caption makes a claim for the liqueur. There are many variations on this pattern.

Absolut Vodka has published a series of brilliant ads, which depend on recognition and surprise for their effect. They all play with name of the brand, "Absolut", which in everyday speech in various languages is a common expression of agreement, and an intensifying term of approval. In these ads "Absolut" becomes an adjective that is often applied to various nouns, especially to names of artists, celebrities, qualities, seasons, cities in the US and Europe, and states of the US. The element of recognition resides in the unique shape of the Absolut vodka bottle that usually forms part of the advertisement's graphic image, and, of course, in the name of the vodka. The magazine Archaeology [fig. 1] devoted the rear cover to "Absolut Athens" and the picture featured a massive column in the shape of the vodka bottle set in a Greek-looking landscape. The choice of Athens was particularly appropriate to a publication concerned with archaeology.

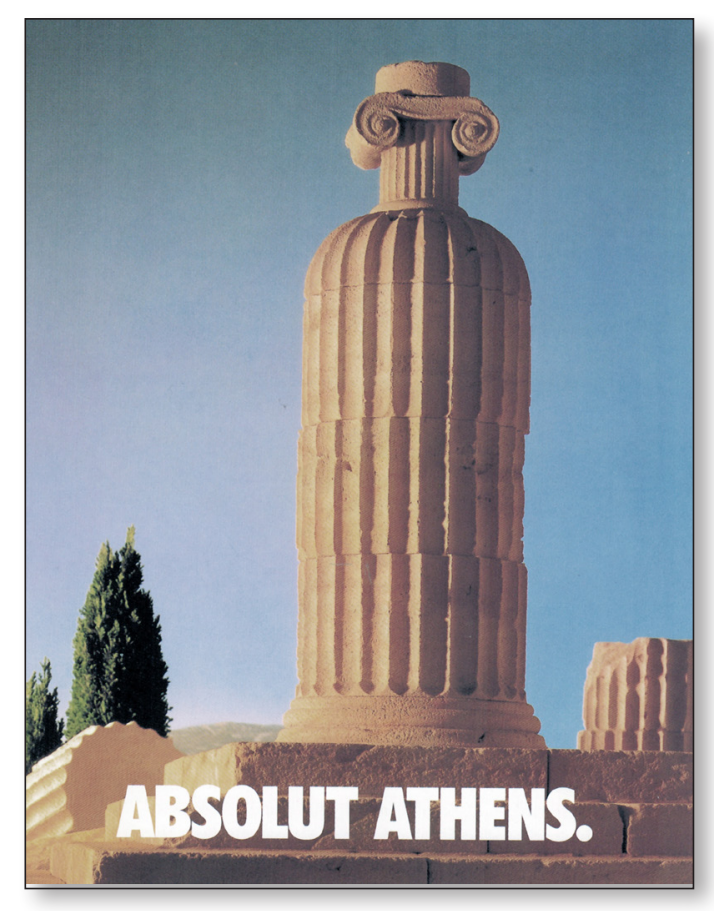

Fig. 1. «Absolut Athens» (Archaeology, November/December, 1996).

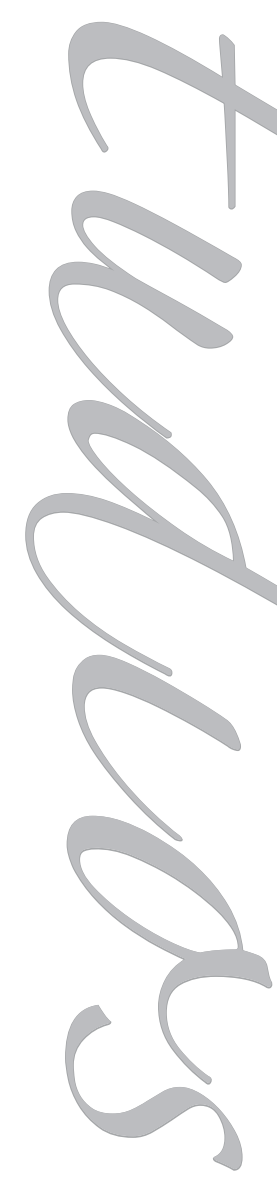

IMAGO, NÚM. 9, 20I7, 87-I05 


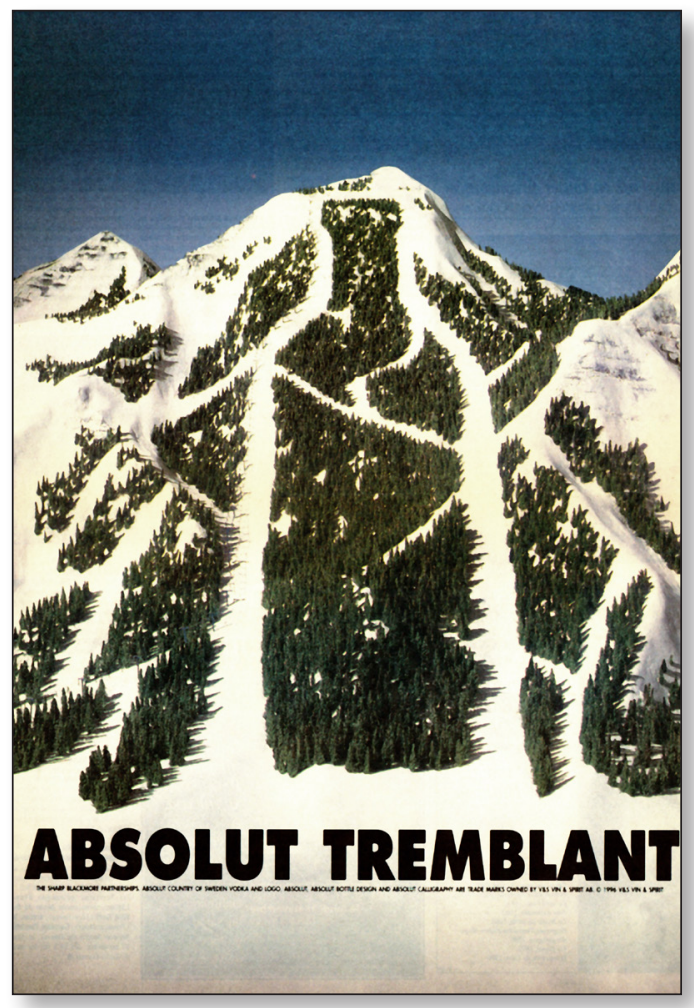

Fig. 2. «Absolut Tremblant» (La Presse, November 14, 1996).

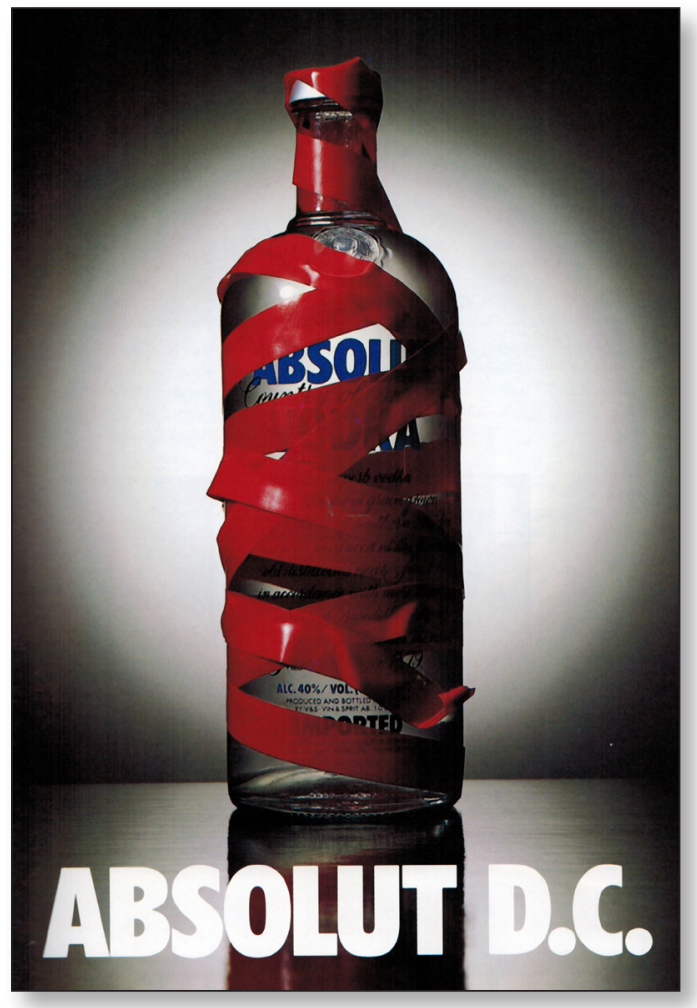

Fig. 3. "Absolute D.C.» (Lewis, 1996: 53).

The Montreal newspaper La Presse of November 14, 1996, devoted an Absolut vodka ad to Tremblant, a famous Quebec key resort [fig. 2].

There is often an element of fun in these Absolut ads. Government and bureaucracy the world over is characterized by a maze of rules and regulations, procedures and forms, for which «red tape» is the universal English phrase. The capital of the United States has its red tape, as we see in the ad, which features an Absolut bottle entangled in red tape and accompanied with the appropriate caption "Absolut D.C.» [fig. 3]. Interestingly, it seems that no other European language uses the exact equivalent of «red tape» for bureaucracy, so this ad can only function in an English-speaking setting. ${ }^{1}$ There have been dozens of such Absolut cities including Amsterdam, Barcelona, Brooklyn, Geneva, Madrid, Miami, Naples, Paris, and Venice. 


\section{RIDDLE AND PUZZLE}

The riddle or puzzle involves the stimulation of a mild intellectual challenge in the reader. Here the advertiser attracts our attention and arouses our interest by presenting us with something like a riddle, or puzzle to solve.

A 1986 issue of the magazine Paris Match displayed a seascape and sunset to advertise Benson $\&$ Hedges cigarettes. The setting sun sends a shaft of gold across the crimson waters of a lake or sea. The shaft of gold points down to the brief text beneath, which functions like the motto of an emblem: "Discover gold».

It is a beautiful image, but we are at first left puzzled by the relationship between the picture and the brief injunction «Discover gold». What gold? Looking more carefully at the reflection of the sun we notice some lettering and decipher «Spec» and "Bens». Smokers will recognise that as a reference to the cigarette «Special» by Benson and Hedges, and «Bens" as referring to "Benson" of Benson and Hedges. The shaft of gold is in fact a partial view of the gold cigarette packet with that lettering. At the top right, running vertically up the side of the picture is the signature "Benson $\delta$ Hedges». The ad has cleverly caught our attention, suggested that the cigarettes are valuable, that in them the smoker will discover gold. The natural scene is tranquil and beautiful disposing the reader positively to receive the message from the cigarette maker. But the primary strategy is, however, the intellectual challenge.

There were many variations. A golden light bulb is inscribed «Benson and Hedges». The motif of the attraction of the moth to the light is as old as Persian love poetry, and it usually denotes the destructive danger inherent in attraction since the moth is singed, often burned by the object it desires. I doubt whether Benson and Hedges thought much about the possible negative implications of the moth and light motif. Of course, cigarette smokers theoretically know of the dangers of the attraction, i.e., addiction. But the advertisement is certainly clever.

\section{WIT AND HUMOUR}

All things being equal, making the consumer smile can make the difference between a sale and no sale. There are many kinds of humour.

Tobacco manufacturers in North America and Britain have to deal today with an increasingly aggressive anti-smoking public, as well as government imposed health warnings. Here humour can be a useful strategy. At least one manufacturer, Benson $\&$ Hedges, has dealt humorously with the anti-smoking lobby.

Benson $\&$ Hedges have continued to employ humour in a series of ads that appeared during 1996 in such magazines as Playboy and Cosmopolitan. Like their British series of riddling images, the 1996 crop is also based on a single idea that is put through a series of variations. All these ads take the same phrase "The length you go to for pleasure», which is then paired with another phrase that can be played with in a humorous and unexpected manner.

There are, of course, many forms of humour and wit. Verbal wit depends on linguistic ability and shared knowledge. Advertisers are usually careful where they place ads that rely on certain kinds of intellectual experience. The makers of the somewhat upmarket brand of

IMAGO, NÚM. 9, 20I7, 87-I05 
English gin Tanqueray evidently know that they can expect readers of the equally upmarket magazine Bon Appétit to appreciate the wit involved in applying the names of the tenses of verbs to this gin. Tanqueray claims to be "A singular experience" and readers can enjoy the application to this gin of the tenses known as future perfect, present perfect and past perfect. These are tenses that we may remember from classes in foreign languages.

Somewhat comparable to an emblem, in this case a multiple emblem, the ad is divided into three sections, each with the distinctive bottle of Tanqueray gin but in a different situation and with a different caption. The first picture shows an unopened bottle with the caption «Future perfect» suggesting that in the future the contents of the bottle will be found to be perfect. Literally, future perfect means that when the gin will have been drunk or enjoyed, it will have been found to be perfect. But the enjoyment is in the future. The second section shows the opened bottle accompanied by a glass of gin and tonic with ice and a slice of lemon, which is "Present perfect", i.e., the gin has been drunk or enjoyed, and has been found to be perfect. The third section shows an empty bottle of Tanqueray gin pointing downwards from which the last drop falls. This is "Past perfect», or the gin had been drunk or enjoyed and was found to have been perfect. Teachers of foreign languages will appreciate this one. And, as always with Tanqueray gin ads, it is "A Singular Experience».

\section{PATRIOTISM}

One of the more obvious strategies of persuasion is patriotism, since it is something that most citizens can be assumed to share both in peace and war. Not only soldiers, weapons and flags may connote patriotism, also prominent statesmen, presidents, sportspeople, buildings, and a wide range of architectural and visual icons can appeal to patriotism. Americans tend to be unself-conscious about their patriotism. My impression is that more national flags will be seen flying from private homes and private gardens in the US than in any other country in the western world.

The American Eagle is both a political and patriotic emblem of the US. It has also been used by many companies to capitalize on patriotic sentiment. Since 1872 the Anheuser-Busch Brewing Company has been using the eagle standing on a shield with the stars and stripes, awkwardly perched through the capital A [fig. 4], which presumably stands for Anheuser-Busch but associates the beer maker with America.

In the Columbus Year of 1992 the Chrysler Corporation [fig. 5] appropriated the American eagle, identified as such by five stars, in a blatant appeal both to patriotism and family values as embodied in the standing figures of a young mother and father all admiringly looking up at the eagle in flight.

The caption reads «Rediscover America" which here means American automobiles, and the brief text beneath the

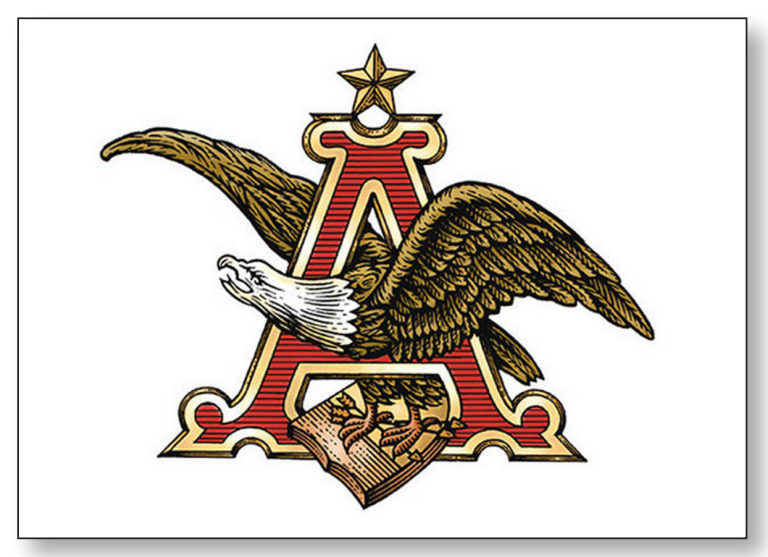

Fig. 4. The Anheuser-Busch logo. 


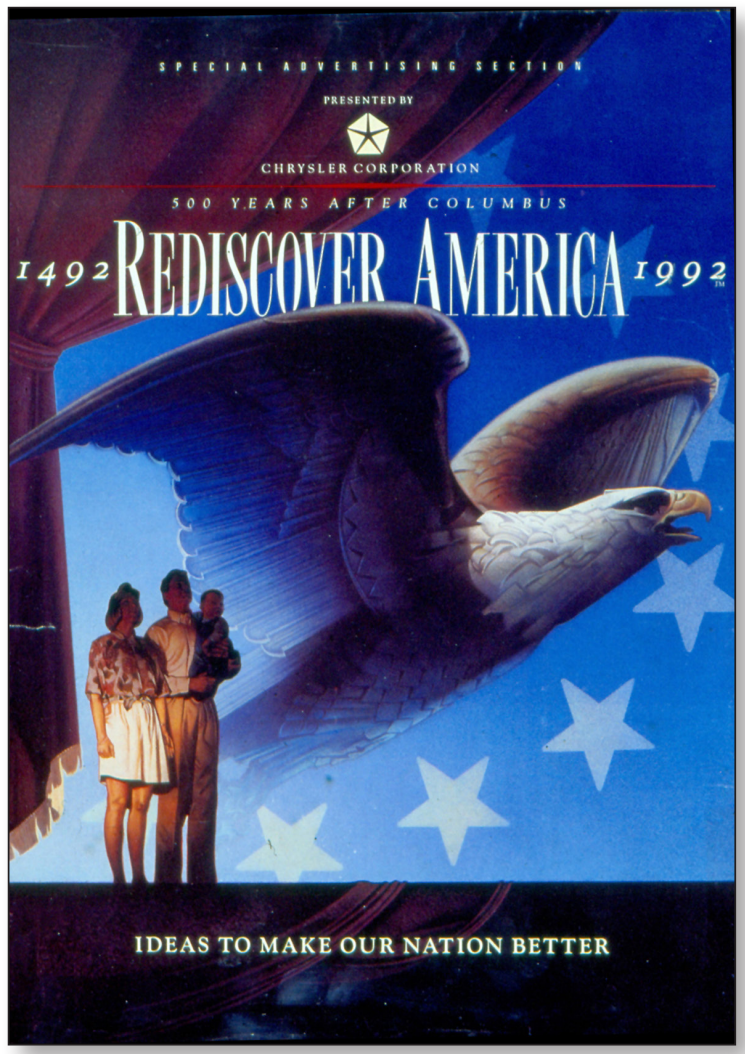

Fig. 5. Chrysler Corporation «Rediscover America» (Life, August, 1992).

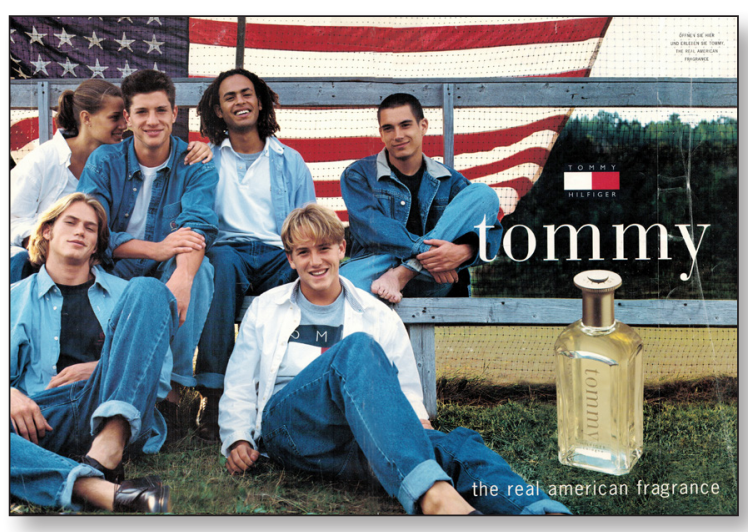

Fig. 6. Hilfiger's «tommy» (Cosmopolitan German, $\mathrm{n}^{\circ} 10$, 1997). picture states with brevity and conviction: «Ideas to make our nation better». This page introduced a description of those better ideas, which produced the cars that American families were being persuaded to rediscover in 1992, the year of Columbus and the Presidential election in which the republicans had made traditional family values an election issue. Business is seen here picking up that lead.

Some American businesses literally wrap themselves in the flag, or at least use it. No matter what the product, the American flag can be appropriated for business. Manufacturers of perfumes will at times wrap their products in the American flag, or display their perfumes against the background of the stars and stripes [fig. 6]. This particular ad combines the backdrop of the American flag with youth, in fact six young people, including one female and one African-American male. Presumably, that choice of young people makes the ad more or less politically correct. Perhaps needless to say, the large bottle of «tommy» is featured, which we are assured is "the real american fragrance», and in small dimensions there is also the logo of Tommy Hilfiger.

In another ad, just to make sure we get the point, the makers of "tommy girl» cologne literally underscored the name "tommy girl» with the statement "A declaration of independence». This must have been a successful ad because it was reissued with slight modifications in a January 1998 issue of Cosmopolitan [fig. 7]. We notice the politically correctness, or the racial correctness, of displaying Caucasian and African-American female models.

Wearing "tommy girl» is supposedly a sign of female independence. But as any intelligent girl or young woman knows, these ads carry an ambiguous message: independence resides in doing what all the other girls are supposedly doing, that is, accepting the message to buy Hilfiger's product. Such ads appear

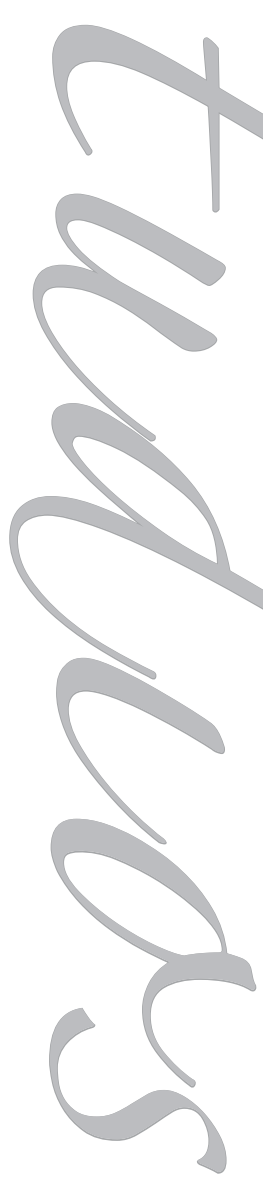


in magazines like YM, Teen, Jump and Seventeen, which advise girls on how to fit in, and this is the direction of most of the advertising. The girl who looks at the reader from Seventeen with her blond hair, blue eyes, and lightly tanned skin is the All-American girl, healthy, happy and carefree. She corresponds nicely with Hilfiger's mission statement: "The Tommy Hilfiger Corporation is dedicated to living the spirit of the American dream [...] the spirit of youth is our greatest inspiration".$^{2}$

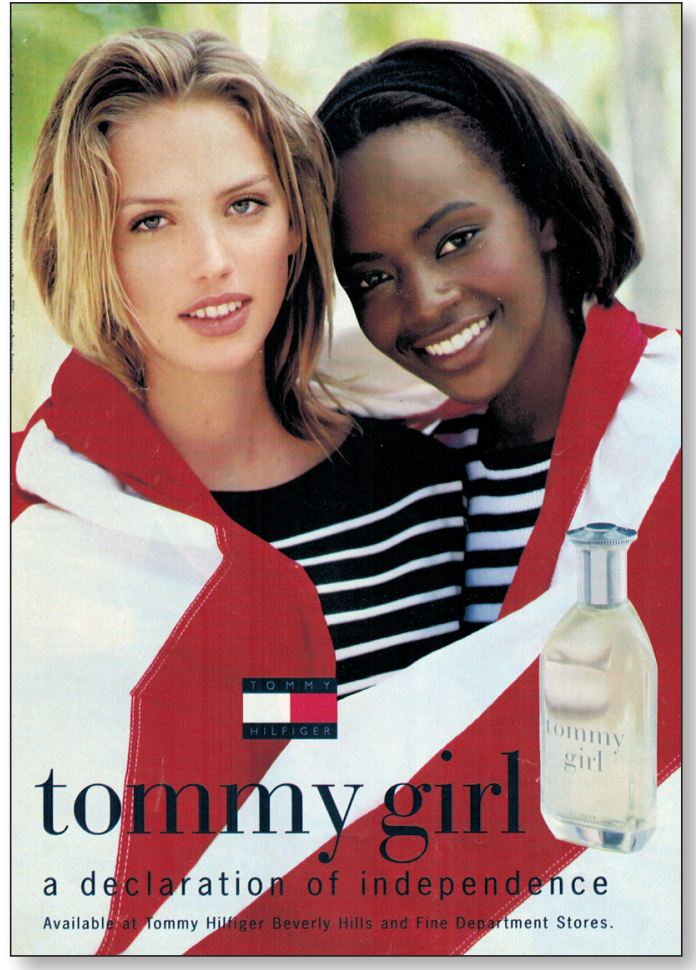

Fig. 7. Hilfiger's «tommy girl» (Cosmopolitan, January, 1998).

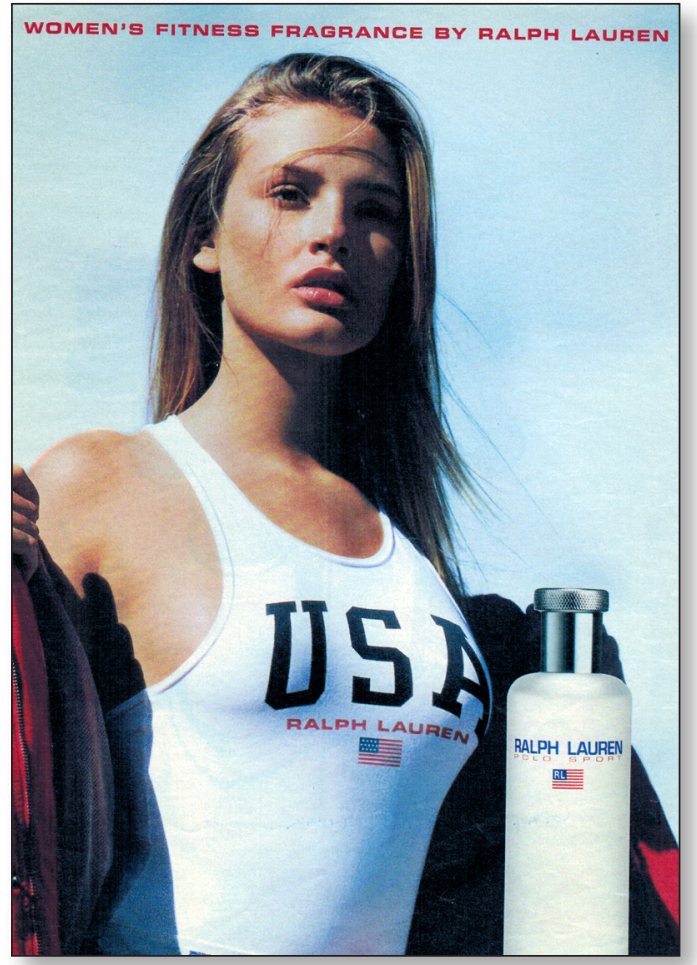

Fig. 8. A female American athlete with Ralph Lauren perfume (Cosmopolitan German, $\mathrm{n}^{\circ}$ 10, 1997).

Ralph Lauren is also in the perfume business, and his company knows that patriotism can sell products. Consequently, the flask of "Polo Sport» carries a modified American flag replete with stripes, the stars having been replaced with the RL for you-know-whom. If sex appeal is added to sport and patriotism, then probably most of the available buttons have been pushed. That is what Ralph Lauren did with later advertising campaigns for "Polo Sport». The following ad appeared in French publication Télérama (May 10, 1997), and in the German edition of Cosmopolitan ( $\mathrm{n}^{\circ} 10$ 1997) [fig. 8] where it carried at the top the English caption «The Women's Fitness Fragrance by Ralph Lauren». It was given wide international publicity.

The flask is now pushed to the side. It still carries the modified American flag but is now labelled "Woman». Two thirds of the full page are given over to a healthy-looking

2. Quoted from the Tommy Hilfiger website: http//www.tommy.com/biz/profile.jhtml (February 20, 2000). 
all-American female athlete with somewhat windblown long blond hair. Her belt is emblazoned with the full American flag and the name Ralph Lauren. She is taking off her red wind breaker, which has the effect of pushing forward her shoulders and chest. Her t-shirt carries the letters USA across her adequate, braless breasts. Her full lips are slightly opened and her facial expression is an invitation. In the summer of 1997 I saw exactly the same image (fig. 8) as a placard on the side of street cars in Antwerp and as displays in pharmacies, not to mention the duty free sections of such in-flight magazines as that of Monarch Airlines In-Flight Magazine, Winter 1997-1998.

Appealing to patriotism goes far beyond borrowing the national flag. Advertisers will sometimes combine an appeal to national sentiment with a famous figure. What better American figure could there be for this purpose than a president of the United States, especially where the historical figure is associated with the nation's past? Past presidents bear famous and familiar faces that have been used to create good will for products as different as chewing tobacco, sugar, smoked meats, life insurance and men's shirts and suspenders.

There are, of course, other patriotic symbols that have been pressed into service. Personifications and architectural icons such as the Tower of London, the Eiffel Tower and the Statue of Liberty come quickly to mind.

\section{FAMOUS PERSONS}

Yet another strategy of persuasion might be called the appeal to the authority of the famous person. The range encompasses patriotic figures like former American presidents to famous persons with no political leverage. It is important that the famous face be easily recognized and instil a sense of confidence.

The famous figures most commonly encountered in contemporary advertising tend to be contemporary personages. But just like the emblem writers, advertisers are careful to maintain credibility by usually ensuring appropriateness. After the Mona Lisa, who is probably the most widely used famous figure in all advertising, it is film stars, sports people and T.V. personalities who most frequently invade our homes, encouraging us to buy this car, that soap, Coca Cola, or something else.

Beautiful women endorse beauty products. Thus Jane Seymour advertises Max Factor products in Cosmopolitan. These beautiful women are not always twenty something.

Super models have immediately recognizable faces, at least for a year or two, and they use not only their faces to promote all manner of products. Cindy Crawford's mole just above the corner of her upper lip, is a virtual trade mark. She is shown in Der Spiegel (1996, $\mathrm{n}^{\circ}$ 18) sporting an Omega watch, and we are told that Cindy Crawford trusts Omega («vertraut auf Omega»). Two years later she is still recommending Omega in Saturday Night of October 1998 [fig. 9].

When it is not the delectable Cindy Crawford, then it is the handsome Pierce Brosnan who poses behind the Omega watch, and also signs a statement that his watch is "Omega by Choice» (Globe $\theta$ Mail, October 10, 1997), Paris Match, and Plaisirs de Vivre (March/April 1999) [fig. 10].

Every nation has its supermodels, who these days are not only modelling fashions, but a bewildering array of consumer products. The more famous the model the larger the ticket item seems to be. 


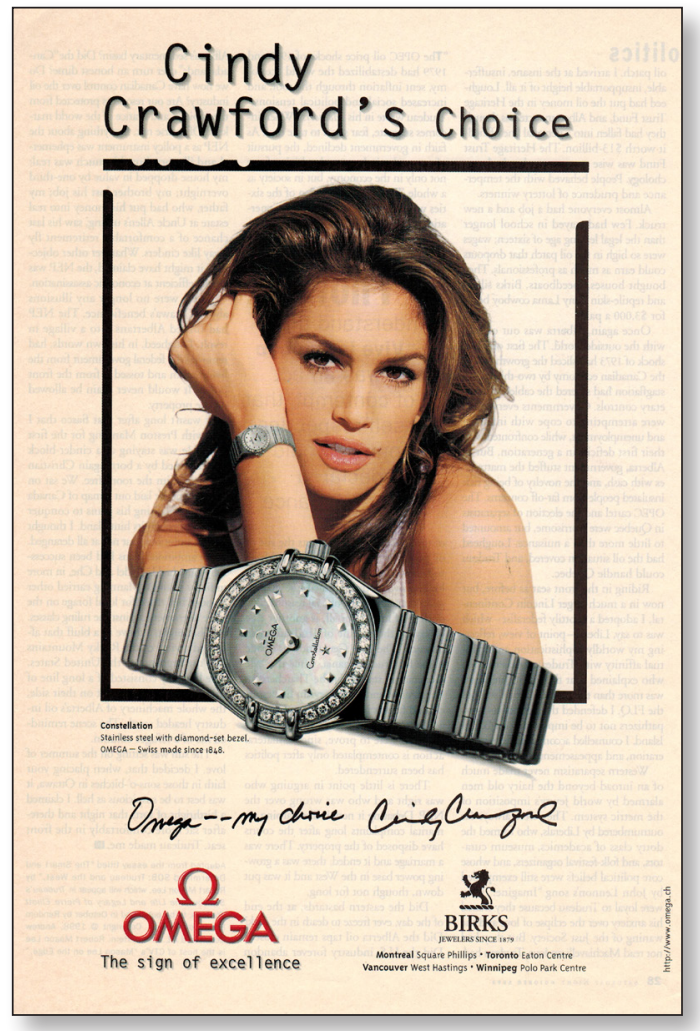

Fig. 9. Cindy Crawford for Omega (Saturday Night, October, 1998).

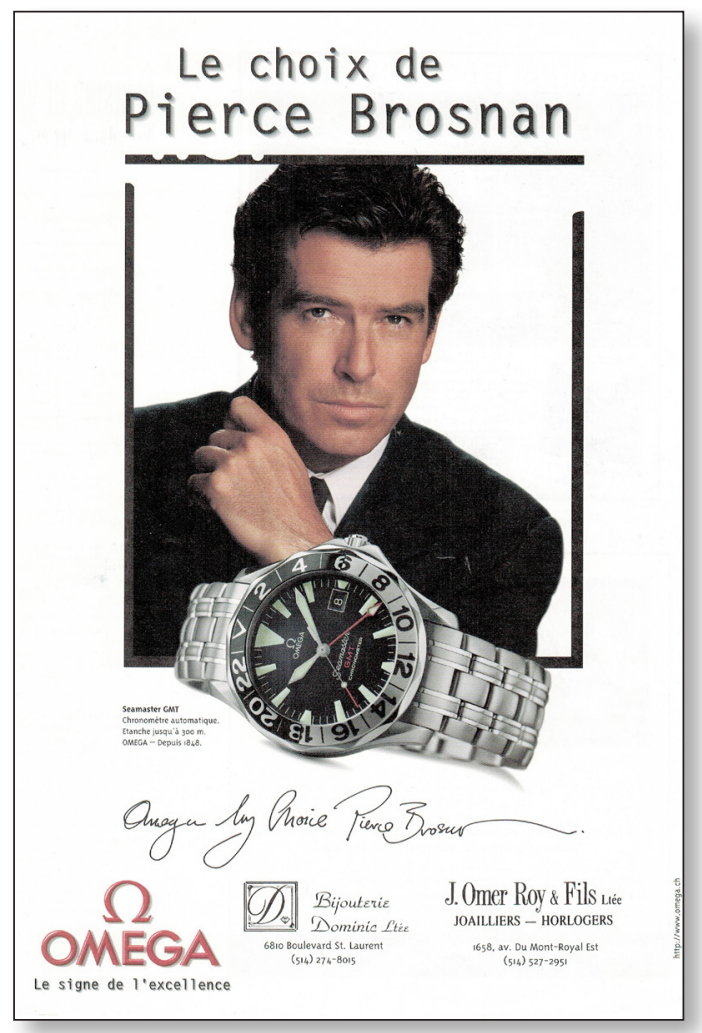

Fig. 10. Pierce Brosnan for Omega (Plasisirs de Vivre, March/April, 1999).

Claudia Schiffer's long blond German hair and longer slender legs [fig. 11] were recruited by the French automobile manufacturer Citroën in a series of ads. Schiffer stands reticently attractive before Citroën's Xsara model. The caption at the top is sober enough: «Der neue Citroën Xsara, einer, dem man vertraut» ( "The new Citroën Xsara, a car that one can trust»). But the caption that runs beneath the German beauty and the French car is an incomplete statement that appears to refer both to Schiffer and the Citroën: "[...] daß Schutzengel so gut aussehen können [...]" ([...] that guardian angels can look so good [...]). And at the bottom of the page is a final caption that refers to the car, but leaves one perhaps thinking of the model: "Nichts bewegt Sie wie ein Citroën» ("Nothing moves you like a Citroën»).

Needless to say, some men also have unforgettable faces that can be pressed into the service of advertising. The men always seem to be older! I prefer not to follow that observation with an interpretation. The famous detective Columbo, or rather his actor, Peter Falk, is immediately recognisable. Advertisers for American Express [fig. 12] have put Columbo to work for them.

On occasion using a famous person to sponsor products is not without its dangers, as Nike found out. Allegedly, the company paid Mr. Jordan some \$45 million to "Just do it» and promote Nike products by wearing them. But two things gradually worked against Nike. One was its own manufacturing practices in labour-cheap East Asian countries, and the other was a certain disillusionment with professional sport and its overpaid stars. 


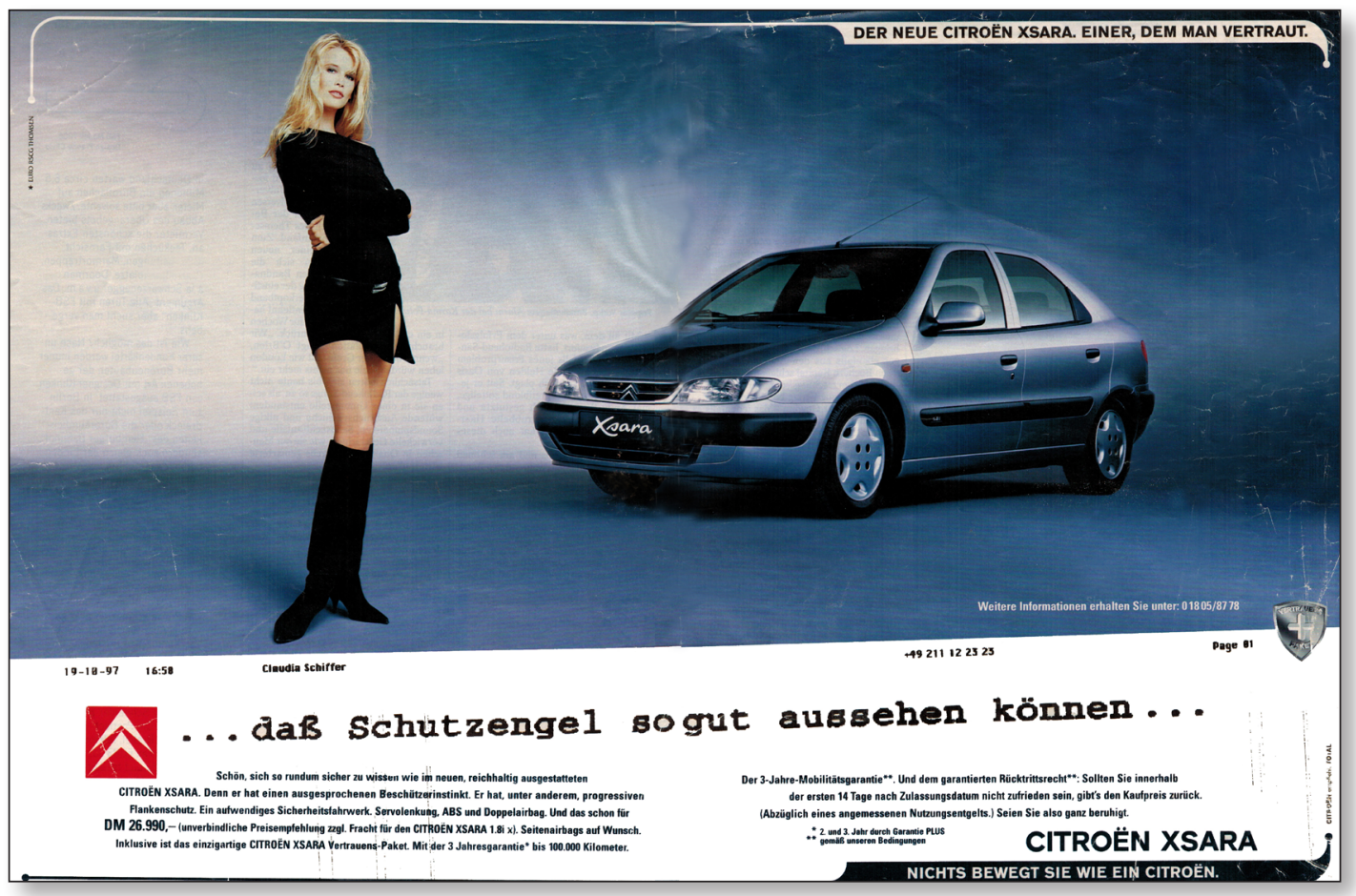

Fig. 11. Claudia Schiffer for Citroën Xsara (Der Spiegel, nº 45, 1997).

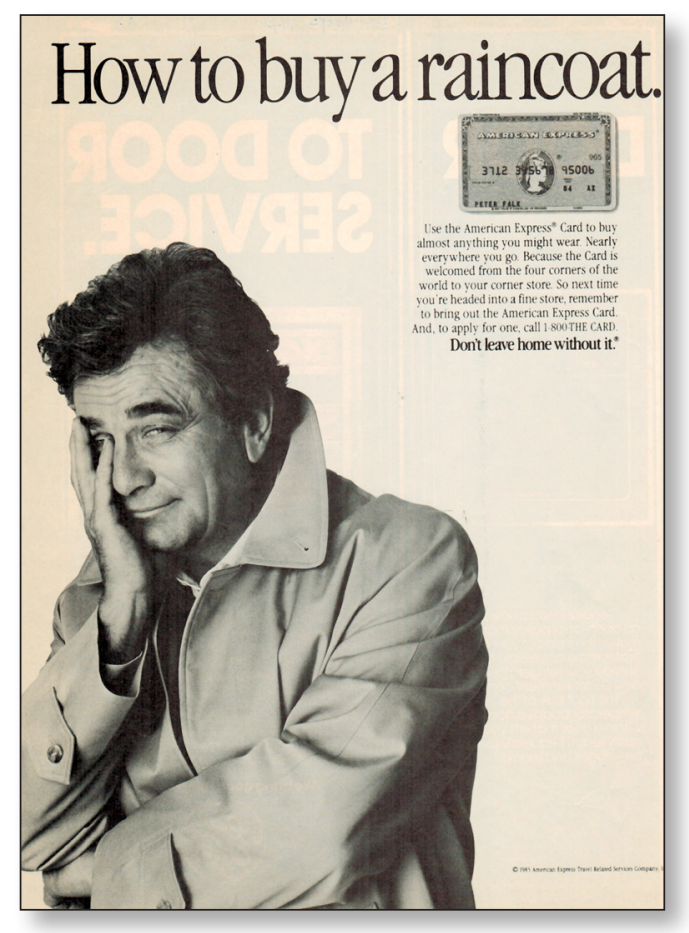

Fig. 12. Peter Falk for American Express. 


\section{MYTH}

Another strategy of persuasion invokes the power of myth, whether classical or more recent. We shall find something essentially similar in modern advertising, which can also use mythology in the attempt to persuade. Antaeus and Atlas appear from the pages of magazines to encourage men to purchase perfumes and deodorants.

There is also a tongue in cheek aspect in which a mythological creature such as a horned unicorn or the Lochness monster is used humorously to advertise a product like a single malt Scotch or a Lincoln luxury car. The unicorn is juxtaposed with a horse with the cap-

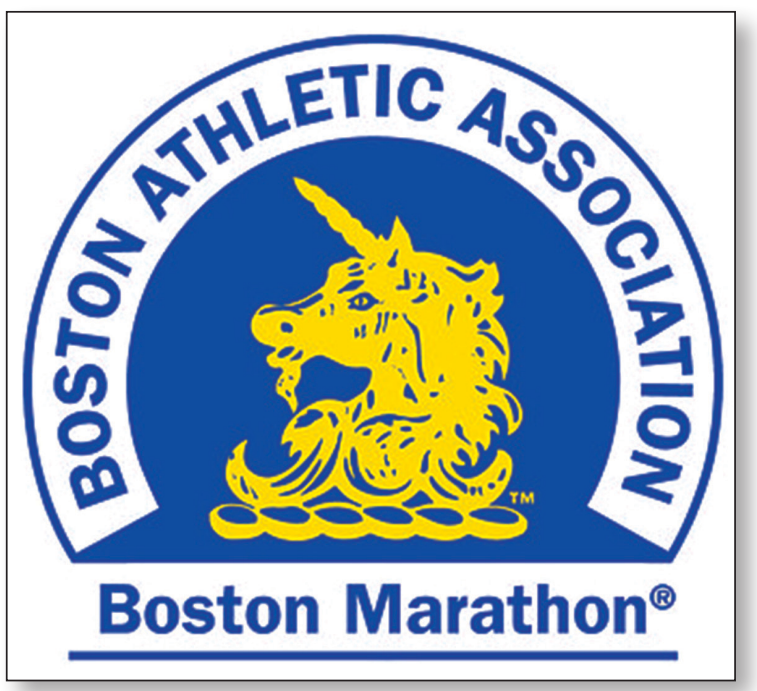

Fig. 13. The logo of the Boston Athletic Association. tion "Some have it, and some don't», referring to the horn but really meaning that there is a difference between an ordinary Scotch and a single malt. The Boston Athletic Association (BAA) has a rather fierce looking unicorn as a logo [fig. 13], which also advertises its marathon race that is the oldest and most prestigious of marathons.

\section{ETHNICITY}

To the extent that advertisers seek to influence white consumers, who have always been in the majority in Europe and North America, they use largely white men and white women to recommend their products and services.

For at least a century, non-white persons have, however, appeared in certain advertisements and on the labels of certain products. One will still encounter Uncle Ben, Rastus and Aunt Jemima in the supermarkets. From this point of view, ethnicity is the presence of non-Caucasians in advertising. We should perhaps remember that advertisers have employed stereotypes from the very beginning. In fact, many of the white figures are stereotypes. They include the domesticated wife, the slinky woman and the dumb blonde, the assertive father and the macho male, who may or may not be depicted riding a horse and smoking a cigarette.

The question arises whether advertising that uses representatives of different races and thereby creates, or reinforces societal attitudes. There is little doubt that much advertising reinforces existing prejudice, whether that prejudice is based on money, sex, race or class, or some potent combination of these. Advertisers will not usually set out to offend consumers. Perhaps the advertising campaign adopted by Benetton, which often appears to seek to shock the public with racial or sexual images, is the exception that proves the rule. While many people will be sceptical of Benetton's intentions, and indeed reject their approach, Benneton's sales have hardly suffered.

Ethnicity as a strategy of persuasion in advertising raises a number of issues, which can be related to questions of intention and reception. We could ask: 
1. What kinds of persons are depicted?

2. How are they represented?

3. What kinds of products or services are they promoting?

4. What is the target audience?

The question of stereotyping also arises. Who are the non-Caucasians featured in illustrated advertisements? At least since the civil rights movements of the 1960s, black has also become almost synonymous with beautiful. Hence the increasing number of black and coloured models in advertising, mostly not named, who promote a wide range of consumer products from perfumes, cosmetics, clothing, sportswear and food products, to cigarettes and soft drinks. The famous supermodels still tend to be white and Naomi Campbell, as famous for her temper as for her looks, ${ }^{3}$ was the exception who proved the rule until recently. During the 1990s advertisers have increasingly featured a coloured or black model.

Then there are the athletes. Marathon running has long been dominated by skinny Africans, and a world record of two hours, five minutes and 42 seconds was set at the 1999 Chicago marathon by the Moroccan, Khalid Khannouchi. But when it comes to athletes, most people will think first of the great boxers of the past, the football players and basketball players, contemporary field and track stars. Their names are legion, their feats are legendary. Names like Mohamed Ali, George Foreman, Michael Jordan, and O. J. Simpson spring to mind. In his time, Sugar Ray Robinson advertised Coca Cola, and today George Foreman may still be seen advertising on CNN. If this is a stereotype, it is not necessarily a negative one. The name is the thing. I do not believe that readers and viewers today think necessarily that all athletes are intellectually or emotionally inferior. Athletes are regarded as high achievers and also as entertainers. Disapproval of athletes' incomes is not infrequently a matter of envy.

What are these ethnic representatives promoting today? In a word, almost everything: sportswear, clothing, perfumes and cosmetics, soft drinks and alcohol, kitchen products and food, cigarettes, watches and cameras. It is less usual to find non-Caucasians advertising cars, financial services, and probably no black woman is shown actually smoking a cigar. That is left for the occasional white female model; and the cigar is seldom in her mouth.

The advertisements of the 1990s perpetuate some old stereotypes, but perhaps less perniciously than in earlier decades. Not all stereotypes represent a disservice. The problem is with the generalizing effect of stereotypes, and here we quickly get into the issue of personal and societal attitudes that in my view advertising attempts to reflect and use.

Aunt Jemima, the famous black woman with the red bandana, has been providing Americans with breakfast for decades. She started out as representing a typical post-slavery happy and humble servant, who was the advertisement for a company that originally produced only pancake flour. The company latched onto an advertising trend that at the end of the nineteenth century increasingly used blacks to recommend food products, gardening and farm implements as well as cleaning products. Blacks were generally thought of as being experienced in the kitchen, in the garden, and on the farm. Thus when a black was shown recommending a given product the white purchaser tended to give some credence to the product (Kern-Foxworth, 1994: 63).

3. See article in National Post, January 22, 2000 entitled «Oh, no, my poor Omi!». This was followed a few days later by an article reporting that the model had pleaded guilty in Ontario provincial court to an assault charge (National Post, 2000, February 3). She had evidently physically attacked her personal assistant, Georgina Galanis. Campbell received an absolute discharge and so will have no criminal record. It was also reported that she had settled out of court the \$2-million civil suit filed by Ms. Galanis. 
It should be clear that such ethnic, indeed, racial ads are not necessarily directed to the ethnic group represented by the colour of the chief actor. They were intended for a white audience. It was assumed that non-Caucasians had relatively little buying power. That has changed.

Unlike Aunt Jemima, Uncle Ben was a real person. Frank Brown was a Maître d' at a Chicago restaurant frequented by the future president of Uncle Ben's Converted Rice company.

Rastus was also a real person and likewise an employee of a Chicago restaurant. His smiling face attracted the attention of Emery Mapaes, one of the founders of the Cream of Wheat company in 1890. A 1909 add shows a little white girl building a figure with alphabet blocks. The man is Rastus and the words "Cream of Wheat» edge the construction.

If Asian women seem to be stereotypically mysterious and submissive, their coloured or black counterparts often appear more independent. The white viewer is no longer shown as superior, as was the case with a 1935 Kodak ad. Independence can be portrayed as provocative, even aggressive, as in an advertisement for the magazine Details, which depicted a tough-looking black man wearing a dark suit, tie and sunglasses, his foot on the tire of a black car. The caption reads: «A Baadassssss offer from Details».

In image after image Benetton juxtaposes a white and black body. In one a black mother suckles a white baby; in another a little white girl cradles a black infant in her arms; in yet another a white man and a black woman modestly hold hands, dressed only in underwear, shown from navel to knee. There were also images of black children kissing under American and Soviet flags, of a white hand handcuffed to a black hand, of white grains of rice in a black hand. Any one of these images could be attacked on racial grounds. Why must it usually be a black woman giving milk? But viewed together they take a stand against racism and celebrate racial togetherness. It is Benetton's way of fulfilling Coca Cola's promise: «I'd like to buy the world a home and furnish it with love».

But many of Benetton's images do shock and do jar the sensitivities of many readers, but evidently not the youthful buyers. A nun dressed in a white habit kisses a priest dressed in black; a black horse mates with a white horse; buttocks and pubic areas are stamped «HIV positive"; a harrowing death scene where an AIDS victim dies; coloured condoms. Images of sexuality and the dangers of AIDS will often offend and shock.

There are also political images. It could be argued that AIDS images are perhaps as political as sexual. Certainly, journalistic photographs of Albanian refugees on a crowded ship off the Italian coast, and a Bosnian soldier's blood-stained clothes are political. They created controversy. But controversy is exactly what Benetton wanted to stir up. To take a strong political or moral stand may cause offense, but in the process the name of the company is unlikely to be forgotten. Sales do not necessarily fall.

What is the target audience for ethnic advertisements? Early appearances of Uncle Ben, Rastus and Aunt Jemima were clearly aimed at a white readership that associated these black Americans with food and service. More recently, it is sometimes difficult to assess whether such ads target one racial group. An image showing an ethnically mixed group will presumably appeal to both white and non-white readers, always discounting the racially biased readers. Black only figures will appeal to non-white viewers, but also to other groups, and may be thought of, or perhaps were intended to be, "progressive». Athletes and entertainers appeal to all groups.

Magazines such as Ebony and Jet were, however, created for and are aimed at a black and coloured readership. 


\section{BIBLICAL AND CHRISTIAN TRADITION}

Advertisers have long deployed motifs of biblical and Christian origin to push products and services. Monks and priests, nuns and angels, religious icons and statues have all done service for commerce. Whether one finds such images blasphemous, in bad taste, funny, or what have you, will depend on individual sensitivities. On occasion, advertisers can stretch tolerance, as can be seen in Volkswagen's French ad for its new Golf.

Smirnoff has used angels, notably attractive male figures with huge wings, and through the bottle a hell's angel may be seen as part of the advertising campaign «through the bottle».

It may be coincidental but most of the commercial uses of Christian motifs seem to come from purveyors of hard spirits. I will admit that I was startled to read an advertisement one Christmas for Remy Martin cognac with the caption "Do unto others [...]». Obviously, Remy Martin expected the reader to be able to complete the statement with "[...] as you would have them do unto you». The ingredients in this ad. are a dash of secular self-interest and doubtful humour, depending on how you regard the Biblical source of the partial quotation.

The pelican-in-her-piety always depicts a mother pelican ripping open her breast to sprinkle her blood on her tiny chicks. It had for centuries been a Christological symbol for Jesus Christ, although there is little reason to think that such a religious motivation lay behind the 1887 advertisement for «Pelican Yeast Powder» issued by the Michel Company of New Orleans [fig. 14].

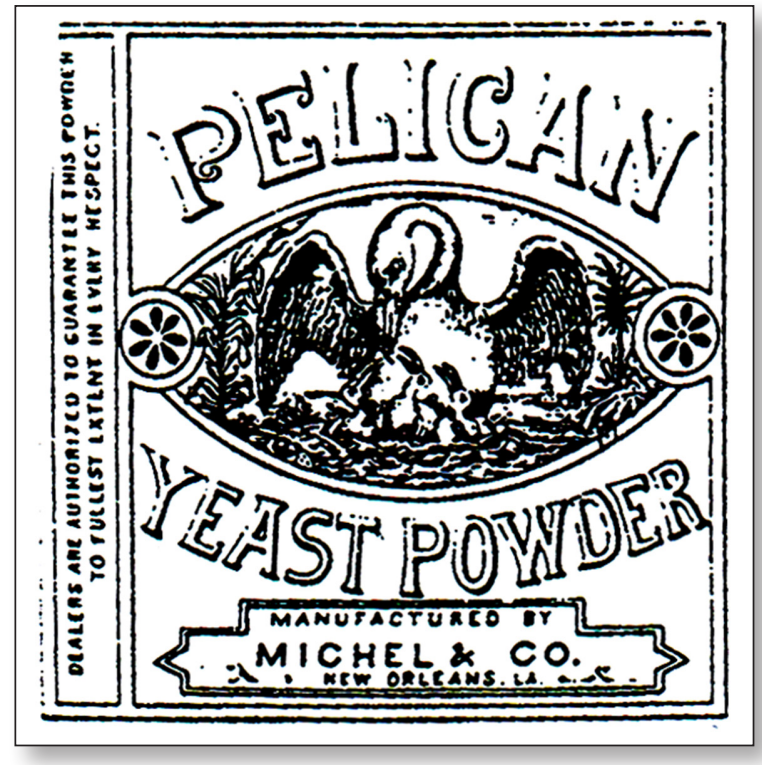

Fig. 14. The pelican-in-her-piety for Michel's Pelican Yeast Powder. 
There are, however, modern instances where blood is the primary reference in the pelican-in-her-piety. The blood transfusion service of Southern Ireland uses the pelican-in-her-piety as its logo or badge. The bird is white and the droplet of blood is, of course, red. The headquarters of the organization is called «Pelican House». After giving ten donations of blood, the individual is presented with a badge showing the pelican giving her blood [fig. 15]. Volunteers who have given fifty donations are presented with a "Gold Drop" Award, accompanied by a scroll with a translated quotation from the fifth-century Byzantine liturgy, which forms a link back to the Christological significance of the pelican, albeit in the context of modern medicine:
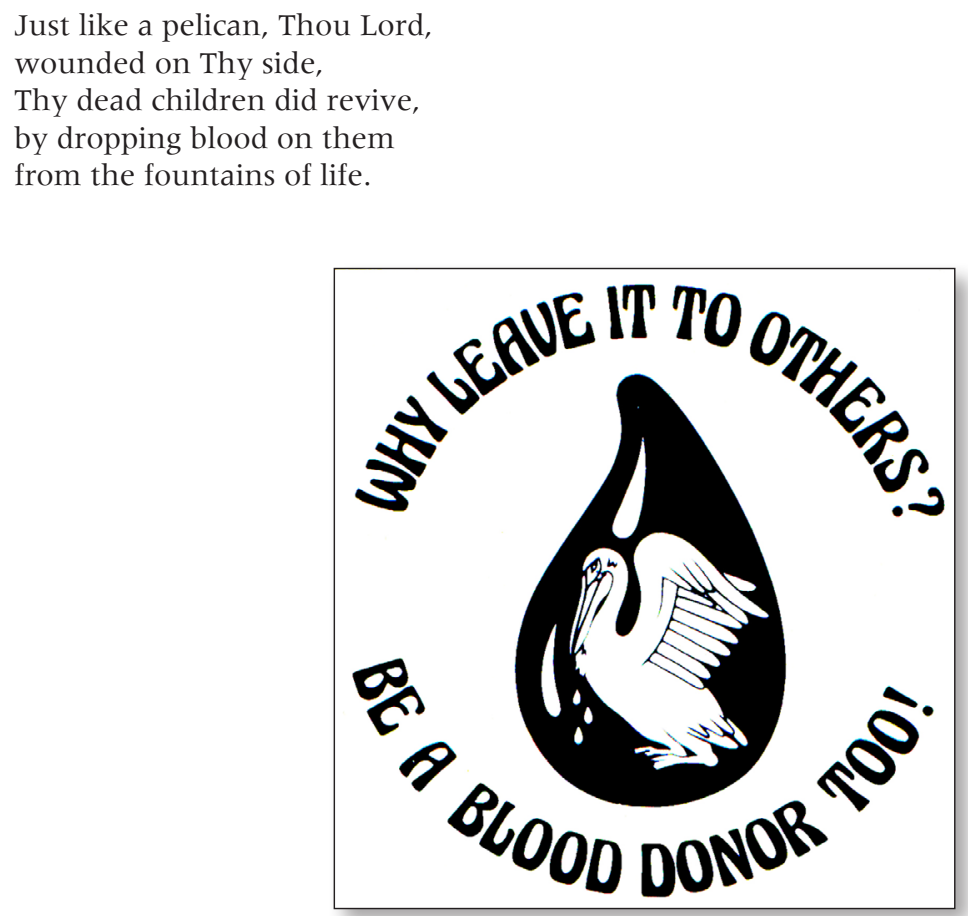

Fig. 15. «Gold Drop» Award of the «Pelican House» Organization.

I have already considered some unlikely uses of Adam and Eve in an essay entitled "Adam and Eve in the Garden of Advertising" (Daly, 1995: 77-88). But I cannot resist the temptation to use one more instance, this time stressing the apple, for an English cider, known as Scrumpy Jack [fig. 16].

\section{NATURE, THE ENVIRONMENT, AND THE ECOLOGY}

The 1990s saw advertisers introduce a new strategy of persuasion-nature, the environment and the ecology. Motherhood was once, and for many people still is, an unquestionable value. Ecology has now joined Motherhood. A contemporary self-evident good is the protec- 


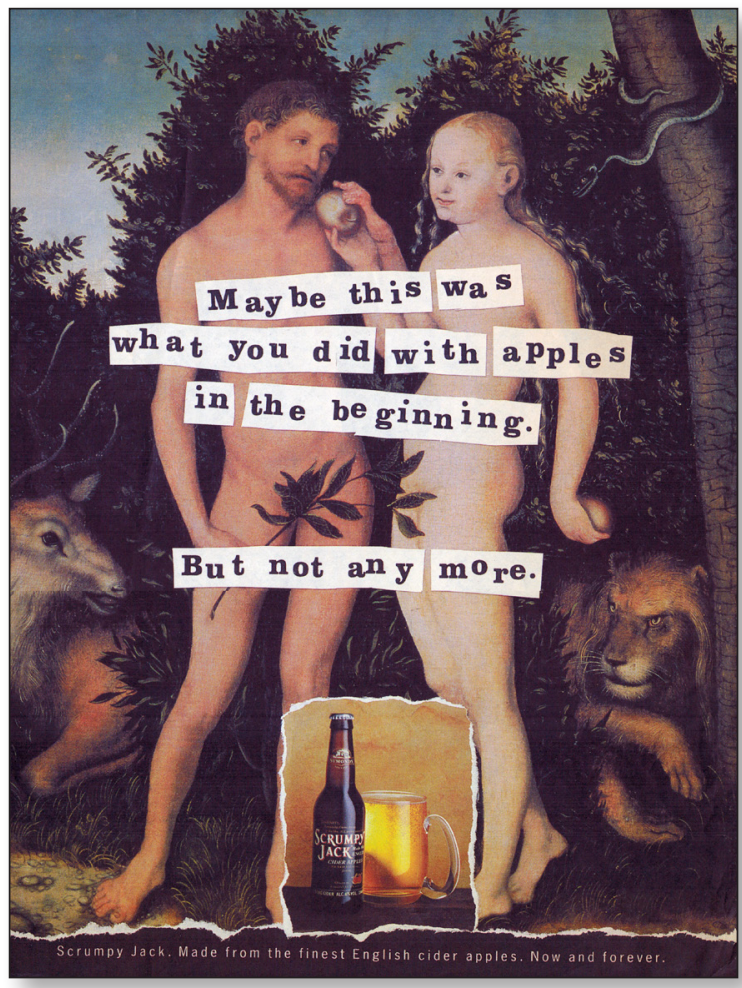

Fig. 16. Adam and Eve for Scrumpy Jack cider (Independent Saturday Magazine, November 29, 1997). tion of the environment. Save the trees, save the whales, save water, save nature. Ecology has become a rallying cry.

We should not be surprised to find that the manufacturers of beers and cars are quickly latching on to these new shared values. GM launched a new series called Geo, with such models as Metro. These are small, more efficient cars, presumably good for the earth, hence Geo.

A forest scene with a baby deer can also be used to praise the ecological qualities of a dishwasher. AEG somewhat incongruously placed its dishwasher, appropriately called «Öko-Favorit $8080 »$, in a woodland setting. The large caption makes the claim with an untranslatable play on words: "Lauter Argumente für unseren leisesten Geschirrspüler» ( "Pure arguments for our quietest dishwasher») (Der Spiegel, 1997: Special $\left.n^{\circ}\right)$. AEG repeated the picture for its 8081 model a little later with a slightly altered text, "Pssst. Unser leister Geschirrspüler ist jetzt auch der sparsamste» ( "Pssst. Our quietest dishwasher is also now the most economical»).

Indeed, forests are becoming a big thing with advertisers. Frequently, however, these forests have little to do with the products themselves. The Globe and Mail Report on Business (May, 1995) carried a twelve page advertising insert for the computer company Compaq. The front page displayed a forest scene with the caption «If A Computer Crashed on Your Network, Would You Hear It?». The final page repeats the full page picture of a forest with the comforting information concerning Compaq's three-year warranty.

If forests can advertise computers, then they can also be used to recommend computer services. If it is not trees in a forest, then it is the cross section of the trunk of an old tree exposing the rings, which indicate age. The Business Development Bank of Canada ran an interesting ad in Macleans featuring a section of a one-hundred-year-old tree, with the slightly humorous caption «How To Grow From Here To There, Without Standing Around For 100 Years». Trees may have nothing in common with banking and loans, but growth does link the two, and so the ad works.

What could call up positive images of nature better than a mother swan leading a column of her cygnets into the water? The German manufacturer of concrete building products, Ytong, used precisely that picture to advertise its nature-friendly products and with the caption "Mensch, bau mit YTONG!» ("Man, build with YTONG»). The slogan "Ytong Building for Man and Nature" asserts what is amply shown in the picture, but hardly demonstrated by the accompanying texts, where the only comment has to do with the insulation qualities of Ytong, which may or may not save heating energy. 
The German Biergesetz ( BBeer law») is known the world over. It guarantees that beer is pure and natural, but «natural» is often a disputed category. For some German breweries the Biergesetz is not enough. In a Spiegel ad. (1991: $n^{\circ}$ 41) Licher appeals to nature [fig. 17]. Licher Pilsner places the picture of an elegant pilsner glass of beer in a natural setting. In fact the glass stands on a flat stone at the edge of a body of water that reflects the greenery of the surroundings. A kingfisher is perched to the left side is apparently studying the beer glass. Somewhat like an emblem the picture is framed with two brief statements. At the top we read: "Die natürlichsten Dinge sind die schönsten» ("The most natural things are the most beautiful»). Below the image Licher makes its claim: "LicheBier. Aus dem Herzen der Natur» ( "Licher beer. From the heart of nature»).

By way of conclusion, may I say that these are just some examples of the strategies that I find in symbolic illustrated advertising.

\section{BIBLIOGRAPHY}

Daly, P. M. [1995]. "Adam and Eve in The Garden of Advertising", in G. E. SzÖNYI (ed.), European Iconography --East and West. Selected Papers of the Szeged International Conference. June 9-12, 1993, Leiden, Brill, 77-88.

Kern-Foxworth, M. [1994]. Aunt Jemima, Uncle Ben, and Rastus: Blacks in Advertising, Yesterday, Today, and Tomorrow, Westport, Connecticut \& London, Greenwood Press.

Lewis, R. W. [1996]. Absolut Book. The Absolut Vodka Advertising Story, Boston, Journey Editions.

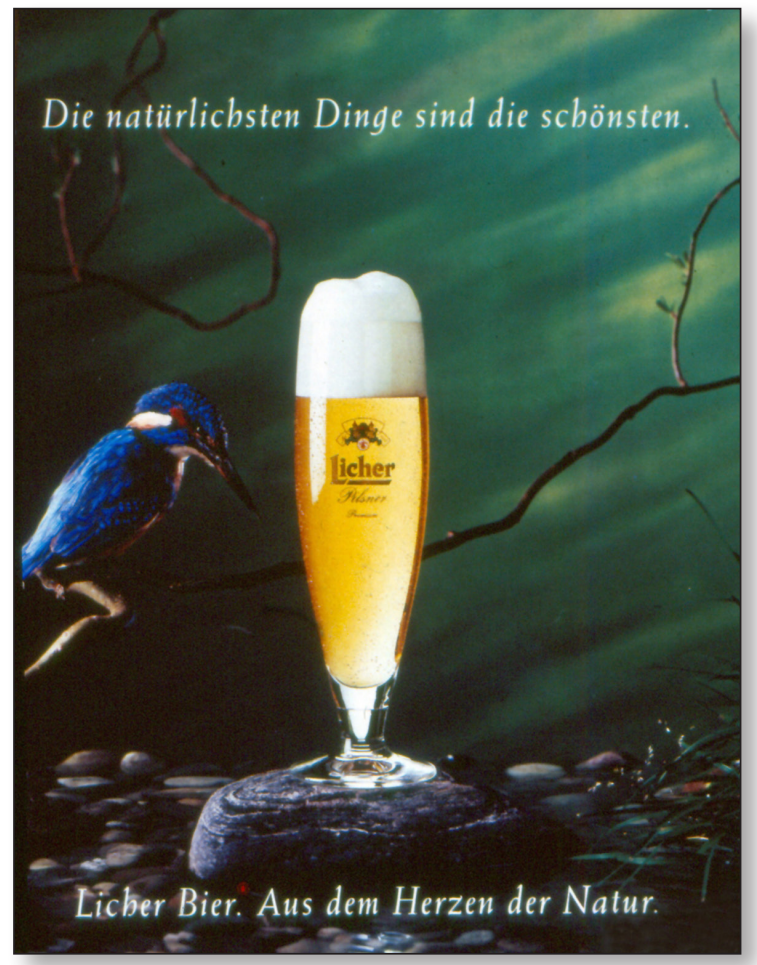

Fig. 17. Licher Pilsner (Der Spiegel, $\mathrm{n}^{\circ}$ 41, 1991).

\section{MAGAZINES, NEWSPAPERS AND \\ OTHERS EUROPEAN \\ AND AMERICAN PUBLICATIONS}

Archaeology (1996: November/December).

Bon Appétit

Cosmopolitan (1996; 1998: January).

Cosmopolitan (German edition, 1997: $\left.n^{\circ} 10\right)$.

Der Spiegel (1991: $\mathrm{n}^{\circ} 41$; 1996: $\mathrm{n}^{\circ} 18$; 1997:

$$
\left.\mathrm{n}^{\mathrm{o}} 45\right) \text {. }
$$

Details

Ebony

Globe e Mail (1997: October 10).

In-Flight Magazine (Monarch Airlines, $1997-$ 1998: Winter).

Independent Saturday Magazine (1997: November 29). 
Jet

Jump

La Presse (Montreal newspaper, 1996: November 14).

Life (1992: August).

National Post (Toronto newspaper, 2000: January 22 and February 3).

Paris Match (1986; 1999: March/April).

Plaisirs de Vivre (1999: March/April).
Playboy (1996).

Saturday Night (1998: October).

Seventeen

Teen

Télérama (French publication, 1997: May 10).

The Globe and Mail Report on Business (1995: May).

$Y M$ 
